\section{Irrigation and Fertilizer Application Methods Affect Performance of High- density Peach Orchards}

\author{
Richard E.C. Layne, Chin S. Tan, and David M. Hunter \\ Agriculture and Agri-Food Canada, Research Centre, Harrow, Ont. NOR IGO, \\ Canada
}

\author{
Robert A. Cline ${ }^{1}$ \\ Ontario Ministry of Agriculture, FoodandRuralAffairs, Horticultural Research \\ Institute of Ontario, Vineland Station, Ont. LOR 2EO, Canada
}

Additional index words. Prunus persica, drip irrigation, microsprinkler irrigation, fertigation, banded fertilizer, soil water

\begin{abstract}
Seven treatment combinations of irrigation and fertilizer were compared in a high-density (606 trees/ha) management system for peach [Prunus persica $(\mathrm{L}$.) Batsch $\mathrm{cv}$. Harrow Beauty/Bailey] on Fox sand in southwestern Ontario. Each treatment combination had an irrigation component $(\mathrm{N}=$ nonirrigated, $\mathrm{D}=$ drip irrigated, or $\mathrm{M}=$ microsprinkler irrigated $)$ and a fertilizer placement component $(B=$ banded fertilizer, $L=$ low fertigation, or $\mathrm{H}=$ high fertigation). NB and DB are commonly used systems in Ontario, while the other five treatment combinations were experimental. Total soil water in the top $110 \mathrm{~cm}$ of soil was lowest under NB but was never at the permanent wilting point. Trunk cross-sectional area was largest under DH and DB, smallest under ML and NB, and intermediate for the other three treatment combinations. No symptoms of $\mathrm{N}$ or $\mathrm{K}$ deficiency or toxicity were noted for any of the fertilizer treatments. Leaf analyses in July and September indicated that most major and minor elements were in the adequate to slightly excess range. However, there were no significant treatment effects on leaf nutrient concentrations in July or September when averaged over the five years, except for Mg in July. There were large and significant year effects on leaf nutrient concentrations but no significant treatment $\times$ year interactions. During the first four cropping years, there were no significant treatment effects, averaged over years, for total yield, marketable yield, or cumulative yield efficiency; however, there were large year effects but no treatment $\times$ year interactions for these factors. There was no detectable yield advantage for D vs. M irrigation. $B$ application of $N$ and $K$ promoted no higher yields than fertigation equivalent to the $B$ rate or $50 \%$ of this rate. Fertigation of $N$ and $K$ during the first 4 years of this experiment did not provide a detectable yield advantage to warrant the added cost and labor associated with this system compared with the $B$ applications of $N$ and $K$.
\end{abstract}

Integrated orchard management systems for peach are a complex of many factors (Layne and Tan, 1984, 1988; Layne et al., 1994a, 1994b). The goal of these systems is to develop fully integrated production systems for peach that optimize the use of land, water, and chemical fertilizers; promote high yields of high-quality fruit; extend orchard life; and increase orchard profitability.

The best soil management practice currently recommended for peaches in Ontario includes establishing permanent creeping red fescue (Festuca rubra L.) sod strips in the row middles after the trees are planted and main-

\footnotetext{
Received for publication 2 Jan. 1996. Accepted for publication 12 Feb. 1996. We acknowledge the excellent technical assistance of M.D. St. Pierre, E.W. Lamoure, M.F. Gadsby, M. Soultani, and D.F. Norton and the statistical advice of V.A. Dirks and P.Y. Jui. The cost of publishing this paper was defrayed in part by the payment of page charges. Under postal regulations, this paper therefore must be hereby marked advertisement solely to indicate this fact.

${ }^{1}$ Retired.
}

taining a weed-free strip with drip irrigation in the tree row (Layne et al., 1994a, 1994b).

Fertigation involves injecting fertilizers, especially $\mathrm{N}$ and $\mathrm{K}$, into irrigation water. As an alternative to broadcast application of fertilizer, fertigation has been used in drip and microsprinkler irrigation systems for tree fruit (Bussi et al., 1991; Edwards et al., 1982; Strabbioli and Colorio, 1988). In some studies, fertilizer applied through the irrigation system was used more efficiently, and, therefore, less fertilizer was required than when broadcast on the soil surface (Edwards et al., 1982; Haynes, 1985). However, Edwards et al. (1982) found that when $\mathrm{N}$ (as $\mathrm{NH}_{4} \mathrm{NO}_{3}$ ) was applied through the irrigation system, soil $\mathrm{pH}$ decreased in the zone wetted by the emitters. This decrease resulted in a high Al concentration in the wetted zone, thereby reducing root density at the emitters, restricting absorption of water, and greatly reducing peach yields. Haynes and Swift (1987) found that soil acidification below the emitters from $\mathrm{N}$ fertigation resulted in significant decreases in levels of exchangeable $\mathrm{Ca}, \mathrm{Mg}$, and $\mathrm{K}$ and increases in levels of exchangeable Al, EDTA-extractable
Fe, Mn, Zn, Al, and bicarbonate-extractable P. Neilsen et al. (1993) found that $\mathrm{Ca}\left(\mathrm{NO}_{3}\right)_{2}$ as the $\mathrm{N}$ source was better than urea or $\mathrm{NH}_{4} \mathrm{NO}_{3}$ for apple (Malus domestica Borkh.) tree growth when the trees were fertigated. Rapid soil acidification beneath and near drip emitters from $\mathrm{N}$ fertigation also was reported for apples (Neilsen et al., 1994) and further emphasized the importance of using the most appropriate form of $\mathrm{N}$ for orchard fertigation.

Drip irrigation effectively overcame the added competition, particularly for water, imposed by permanent sod strips in the row middles and resulted in better peach tree growth and higher marketable yields than no irrigation (Layne and Tan, 1988; Layne et al., 1994a). Microsprinkler irrigation produced a larger but shallower wetting pattern on sandy soils than drip irrigation (Pelletier and Tan, 1993) and might be advantageous for newly planted trees that have a small root system.

Our experiment was designed to critically assess seven combinations of irrigation and fertilization for a high-density management system for peaches, where ground cover consisted of herbicide-killed sod in the tree row and living sod in the row middles.

\section{Materials and Methods}

The orchard site was located at the Ridge Farm of the Harrow Research Centre $\left(\approx 42^{\circ} \mathrm{N}\right.$, $\left.82^{\circ} 54^{\prime} \mathrm{W}\right)$. The experiment was conducted on Fox sand (Hapludalf) that contained $84 \%$ sand, $11 \%$ silt, and $5 \%$ clay from a 0 - to 20 -cm depth and $86 \%$ sand, $10 \%$ silt, and $4 \%$ clay from 20 to $110 \mathrm{~cm}$. Field capacities (FC) defined as 0.1 bar were $0.207 \mathrm{~m}^{3} \cdot \mathrm{m}^{-3}$ from 0 to $20 \mathrm{~cm}$ and $0.172 \mathrm{~m}^{3} \cdot \mathrm{m}^{-3}$ from 20 to $110 \mathrm{~cm}$. Permanent wilting points (PWP) defined as 15 bars were $0.067 \mathrm{~m}^{3} \cdot \mathrm{m}^{-3}$ from 0 to $20 \mathrm{~cm}$ and 0.057 $\mathrm{m}^{3} \cdot \mathrm{m}^{-3}$ from $20 \mathrm{~cm}$ downward. The soil water in the top $110 \mathrm{~cm}$ of the soil profile at FC and PWP was 210 and $55 \mathrm{~mm}$, respectively.

The soil was fumigated to a minimum depth of $20 \mathrm{~cm}$ in Apr. 1987 with 1,3 dichloropropene + trichloronitromethane (chloropicrin) (Telone-IIB, Telone-C17 at 340 liters.ha ${ }^{-1}$ ) to control root-lesion nematodes (Pratylenchus penetrans Cobb), the major nematode pest in Ontario peach orchards (Townshend et al., 1984). Creeping red fescue was seeded at $30 \mathrm{~kg} \cdot \mathrm{ha}^{-1} 2$ weeks after soil aeration. The site was sprinkler-irrigated during the 1987 growing season to assist in sod establishment. On 31 Mar. 1988, dolomitic limestone had been broadcast at 2 t $\cdot \mathrm{ha}^{-1}$; then on 13 Apr. 1988, fertilizer (10N-20P-30K) was broadcast at $224 \mathrm{~kg} \cdot \mathrm{ha}^{-1}$. On $27 \mathrm{Apr}$. 1988, 1-year-old nursery trees of 'Harrow Beauty'/Bailey were planted into killed sod strips ( $1.5 \mathrm{~m}$ in width) that had been sprayed with glyphosate (a.i. at $0.9 \mathrm{~kg} \cdot \mathrm{ha}^{-1}$ ) 4 weeks earlier. Tree spacing was $5.5 \mathrm{~m}$ between rows and $3.0 \mathrm{~m}$ between trees within the row (606 trees/ha). Rows were oriented north to south to optimize light interception, and trees were trained to a modified central leader system. During the planting year, overhead sprinkler irrigation was used as required to assist in tree establishment. 
Irrigation systems were installed in early 1989, and fertigation and irrigation treatments were initiated in May. Irrigation treatments consisted of drip (D), microsprinkler (M), and no irrigation $(\mathrm{N})$. D included two pressurecompensated emitters per tree (NETAFIM Irrigation, New York), each with a flow rate of 4.5 liters $\cdot \mathrm{h}^{-1}$ at $138 \mathrm{kPa}$. The emitters were inserted into 13-mm (internal diameter) polyethylene pipe and placed 45 to $60 \mathrm{~cm}$ from the tree base on the north and south of each tree. $\mathrm{M}$ included one microjet (SOLCOOR, Los Angeles) located $5 \mathrm{~cm}$ from the base of each tree, with a $360^{\circ}$ spray pattern and a flow rate of 28.9 liters $\cdot \mathrm{h}^{-1}$ at $138 \mathrm{kPa}$, giving a wetting pattern $\approx 1.5 \mathrm{~m}$ in diameter. The irrigation amount and frequency for $\mathrm{D}$ and $\mathrm{M}$ were determined using corrected, long-term evaporation data derived from a class $\mathrm{A}$ pan at a nearby weather station, tree age and density, number of emitters or microsprinkler, and soi moisture retention characteristics (Tan and Layne, 1990, 1991). Irrigation treatments began in April each year from 1990 to 1993 and were terminated following the last harvest (late August). The seasonal average irrigation amount for $\mathrm{D}$ was $\approx 50 \%$ of the irrigation amount applied by $\mathrm{M}$.

Soil-water content was monitored using a subsurface neutron moisture probe (modelCPN 503; Campbell Pacific, Martinez, Calif.). Aluminum tubes were inserted to a depth of 120 $\mathrm{cm}$ within the herbicide strip in the middle of the four-tree plots for all replications and were located $1.5 \mathrm{~m}$ from the tree trunk, $1.0 \mathrm{~m}$ from the drip emitter, and $1.5 \mathrm{~m}$ from the microsprinkler. Soil-water measurements were taken two to three times per week each summer (June, July, and August) and monthly in spring and fall at $20-\mathrm{cm}$ intervals from the 20 to $100-\mathrm{cm}$ depths. The neutron probe was calibrated against gravimetric sampling for this particular soil having the following calibration equation: $\theta_{\mathrm{v}}=0.166 \mathrm{R} \div \mathrm{R}_{\mathrm{w}}+0.023$, with $\mathrm{r}^{2}=0.992$ and $S_{\mathrm{yx}}=0.006$, where $\theta_{\mathrm{v}}$ is the volumetric water content, $R$ is the actual count in the soil, and $\mathrm{R}_{\mathrm{w}}$ is the standard count of the probe in the shield.

The amounts of fertilizer used for banded (B) treatments were standard recommended amounts of $\mathrm{N}$ as $\mathrm{Ca}\left(\mathrm{NO}_{3}\right)_{2}$ and $\mathrm{K}$ as $\mathrm{K}_{2} \mathrm{SO}_{4}$ per tree for cultivated orchards in Ontario and were applied to the tree drip line (Ontario Ministry of Agriculture and Food, 1994-1995). The sod was fertilized each year by direct application of $\mathrm{NH}_{4} \mathrm{NO}_{3}$ at $100 \mathrm{~kg} \cdot \mathrm{ha}^{-1}$ using a 2-m-wide lime drill; no K was applied to the sod.

Fertigation for years 1989 to 1993 involved two amounts of $\mathrm{N}$ and $\mathrm{K}$. The high amount $(\mathrm{H})$ was the equivalent of the $\mathrm{B}$ amount of $\mathrm{N}$ and $\mathrm{K}$ each year, while the low amount (L) was $50 \%$ of the B amount. Fertigation was initiated in April of each year, except for 1989, when it was in May, and was terminated each year at the end of August. Irrigation timing and amount were regulated by a controller (model M1c-8; Rainbird, Glendora, Calif.)

The required amount of $\mathrm{N}$ was applied to fertigated plots as follows: one-third of the annual $\mathrm{N}$ required was injected in a single application as a solution of $\mathrm{Ca}\left(\mathrm{NO}_{3}\right)_{2}$ through the irrigation system in early to mid-April, at the same time as BN applications were made. In 1989, because the irrigation system was not installed until early May, this first application of $\mathrm{N}$ was banded at the drip line. Each year, the balance of required $\mathrm{N}$ was applied throughout May and June as a 30-min pulse toward the end of each irrigation, followed by a 30-min flush of the system to prevent crystallization and clogging of emitters. Nitrogen fertigation was terminated by 30 June each year. Potassium as $\mathrm{K}_{2} \mathrm{SO}_{4}$ applications were made in a similar manner throughout July and August, with the banded K application being made at the beginning of July (see Table 1).

Each growing season, healthy, fully expanded leaves for analysis were sampled from the middle of the current-season's extension shoot growth in mid-July and mid-September, 2 weeks after termination of $\mathrm{N}$ and $\mathrm{K}$ fertigations, respectively. The mid-July sample coincided with the standard time of sampling in Ontario for leaf nutrient analysis of commercial peach orchards. A sample of 10 to 15 leaves per tree (50 to 60 leaves per plot) was collected, dried at $40 \mathrm{C}$, and ground to pass through a 2-mm screen. Nutrients in the leaves were determined by standard laboratory analytical procedures (Jones, 1984).

The design was a randomized complete block comprising seven treatments and four replications, where each replication comprised a tree row. There were four trees of 'Harrow Beauty'/Bailey per plot, and plots were separated by a guard tree of 'Harcrest'/Bailey. In addition, each of the four replications was separated by guard rows of 'Harcrest'/Bailey, at the same spacing and training system as for experimental trees.

Trees were pruned annually, immediately after bloom, to reduce vulnerability to canker (Leucostoma spp.) infection (Biggs, 1989). Trees were allowed to fill their allotted space and then were maintained subsequently at a maximum height of $3.0 \mathrm{~m}$, a maximum spread of $3.0 \mathrm{~m}$ at the base of the canopy, and a maximum spread of $\approx 2.5 \mathrm{~m}$ at the top of the canopy, providing a trapezoid shape in the tree row. All trees had filled their allotted space by Fall 1992. Trunk circumference measurements were taken annually, $20 \mathrm{~cm}$ above the soil surface and were converted to trunk crosssectional area (TCA) (Layne and Jui, 1994). Trees were defruited in the first (1988) and

Table 1. Annual amounts of $\mathrm{N}$ and $\mathrm{K}$ applied.

\begin{tabular}{|c|c|c|c|c|c|c|}
\hline \multirow[b]{3}{*}{ Year } & \multicolumn{3}{|c|}{$\mathrm{N}$ (g/tree yearly) } & \multicolumn{3}{|c|}{ K (g/tree yearly) } \\
\hline & \multirow[b]{2}{*}{ Banded $^{\mathrm{z}}$} & \multicolumn{2}{|c|}{ Fertigated } & \multirow[b]{2}{*}{ Banded } & \multicolumn{2}{|c|}{ Fertigated } \\
\hline & & $\overline{\text { High }^{y}}$ & $\overline{\text { Low }^{x}}$ & & High & Low \\
\hline 1989 & 34 & 34 & 17 & 43 & 43 & 22 \\
\hline 1990 & 51 & 51 & 26 & 52 & 52 & 26 \\
\hline 1991 & 68 & 68 & 34 & $0^{\mathrm{w}}$ & $0^{\mathrm{w}}$ & $0^{\mathrm{w}}$ \\
\hline 1992 & 93 & 93 & 46 & 52 & 52 & 26 \\
\hline 1993 & 108 & 108 & 54 & 52 & 52 & 26 \\
\hline
\end{tabular}

${ }^{2}$ Banded treatments are nonirrigated, banded fertilizer; drip irrigated, banded fertilizer; and microsprinkler irrigated, banded fertilizer.

${ }^{y}$ High fertigation treatments are drip irrigated, high fertigation and microsprinkler irrigated, high fertigation. ${ }^{x}$ Low fertigation treatments are drip irrigation, low fertigation and microsprinkler irrigated, low fertigation. wIn 1991, broadcast application of $225 \mathrm{~kg} \cdot \mathrm{ha}^{-1}$ of $0 \mathrm{~N}-10 \mathrm{P}-30 \mathrm{~K}$ was made in error; consequently, no banded or fertigated applications of $\mathrm{K}$ were made in 1991. second (1989) year to optimize vegetative growth but were allowed to crop in subsequent years (1990 to 1993). Fruit were hand-thinned each year, as required, and spaced $\approx 15 \mathrm{~cm}$ apart on fruiting shoots. Yields (kilograms per plot) were recorded annually beginning in the third year (1990). There were three harvests per season, with fruit being harvested at commercial maturity. Total yields were the sum of each harvest per plot before grading. From each plot, a sample $(\approx 28 \mathrm{~kg})$ of fruit was taken from the second harvest for grading. Split pits were weighed separately as were fruit $<5.7 \mathrm{~cm}$ in diameter, both of which are unmarketable grades. The remaining fruit then were graded into three marketable size classes designated as large $(>7.0 \mathrm{~cm})$, medium $(>6.0 \mathrm{~cm}$ to $\leq 7.0$ $\mathrm{cm})$, and small $(>5.7$ to $\leq 6.0 \mathrm{~cm})$. The proportion of the total yield that was marketable, based on the graded samples, comprised the marketable yield. Annual yield efficiency (AYE) was obtained by the following equation: $\mathrm{AYE}=\frac{\mathrm{yield} / \mathrm{plot}}{\mathrm{TCA} / \mathrm{plot}}$. Cumulative yield efficiency (CYE) was obtained by the following equation: $\mathrm{CYE}=\frac{\Sigma \text { yield/plot }(1990-1993)}{\text { TCA/plot }(1993)}$.

To assess land-use efficiency and for direct comparison of experimental yields with commercial practice, yields were converted from kilograms per plot to tons per hectare. Analysis of variance (ANOVA) for a randomized complete-block design (PROC and GLM; SAS Institute, Cary, N.C.) was used for the growth, yield, and yield efficiency data. The leaf nutrient data as well as the total and marketable yields were pooled over years and analyzed as a split plot in time (Layne and Jui, 1994). Duncan's multiple range test was used to compare main effect treatments when $\mathrm{F}$ was significant.

\section{Results}

Seasonal precipitation. The driest growing season (1988) was $16 \%$ drier than the longterm mean for the same period (Table 2), while the wettest growing season (1989) was $129 \%$ wetter than the long-term mean. The remaining four growing seasons ranged from as little as $6 \%$ to as much as $31 \%$ wetter than the longterm mean. May was drier than normal in 1988, 1992, and 1993 and wetter than normal in the other 3 years. June was drier than normal 
in 1988, 1990, 1991, and 1992 and wetter than normal in 1989 and 1993. July was drier than normal in 1990 and 1991 but wetter than nor$\mathrm{mal}$ in the other four years. August was drier than normal in 1993, while for the other five years, it was wetter than normal.

Total soil water. In the top $110 \mathrm{~cm}$ of soil, total soil water was always above the PWP, regardless of treatment (data not shown). Soilwater levels were usually lowest each year in July and August, and over the five years that irrigation treatments were applied (1989-93), soil water attained its lowest levels in Summer 1991 (Fig. 1) and 1993 (data not shown). In 1989 , a year with frequent heavy rains, total soil-water content from June to December was generally high, well above the PWP and around FC, regardless of treatment (data not shown). In 1990 (data not shown) and 1991, the N plots had the lowest total soil-water content; $\mathrm{M}$ plots were intermediate, while D were the highest (Fig. 1). In 1992, only the N plots had substantially lower total soil-water content from May to September than the other six (data not shown). In 1993, lack of irrigation again was associated with the lowest soil-water content from June to November, while the other six treatments were similar for the same period.

Leaf nutrient analysis. Although nutrient concentrations differed among years, there were no treatment $\times$ year interactions; therefore, treatment means were pooled over years (1989-93). With the exception of Mg in July samples (when DL had higher Mg than the other treatments), there were no other significant treatment effects ( $\mathrm{F}$ test) for the pooled data, and, therefore, they are not presented.

Nitrogen. In 1989 (the first year of treatments), $\mathrm{N}$ concentrations in July were slightly lower than the normal Ontario recommended range for nonproducing peach trees (i.e., 3.6\% to $4.3 \%$ dry weight). For the 3 -year period (1990-92), $\mathrm{N}$ concentrations $(3.4 \%$ to $4.1 \%$ dry weight) were in the normal to slightly excess range for bearing trees; while in 1993, $\mathrm{N}$ concentrations $(4.2 \%$ to $4.6 \%$ dry weight) were slightly above the normal recommended range for bearing trees, regardless of treatment.

Potassium. For July and September sample dates, concentrations of $\mathrm{K}$ were within the normal recommended range in Ontario for samples taken in July (2.3\% to $3.5 \%$ dry weight).

Calcium. Calcium nitrate was used as the $\mathrm{N}$ source in this study; thus, Ca was applied in conjunction with $\mathrm{N}$ during April, May, and June. Calcium concentrations were in the normal range ( $1.0 \%$ to $2.5 \%$ dry weight) recommended in Ontario for samples taken in July. Samples taken in September were higher in $\mathrm{Ca}$ than July samples.

Magnesium. No $\mathrm{Mg}$ was applied during this experiment. $\mathrm{Mg}$ concentrations are reported because of the competition between $\mathrm{K}$ and $\mathrm{Mg}$. The recommended range in Ontario for leaf $\mathrm{Mg}$ in July is $0.3 \%$ to $0.6 \%$ dry weight. Throughout this study, leaf $\mathrm{Mg}$ concentrations were within this recommended range. July samples had slightly higher $\mathrm{Mg}$ concentrations than September samples.
Table 2. Monthly and total precipitation (in millimeters) during the growing season for the experimental period (1988-93) and the long-term monthly mean. ${ }^{2}$

\begin{tabular}{lrrrrr}
\hline \hline Year & May & June & July & August & Total $^{\text {y }}$ \\
\hline 1988 & 14 & 23 & 110 & 96 & 243 \\
1989 & 166 & 116 & 299 & 88 & 670 \\
1990 & 117 & 59 & 49 & 117 & 342 \\
1991 & 102 & 27 & 17 & 235 & 382 \\
1992 & 38 & 39 & 132 & 111 & 319 \\
1993 & 54 & 135 & 76 & 43 & 309 \\
Long-term mean (76 years) & 70 & 77 & 71 & 73 & 292 \\
\hline
\end{tabular}

${ }^{2}$ Data from the weather station at the Harrow Research Centre (lat. $\approx 42^{\circ} \mathrm{N}$, long. $\approx 82^{\circ} 54^{\prime} \mathrm{W}$ ) $\approx 6 \mathrm{~km}$ from the experimental orchard and at similar elevation.

${ }^{\mathrm{y}}$ Total $=$ May to August.

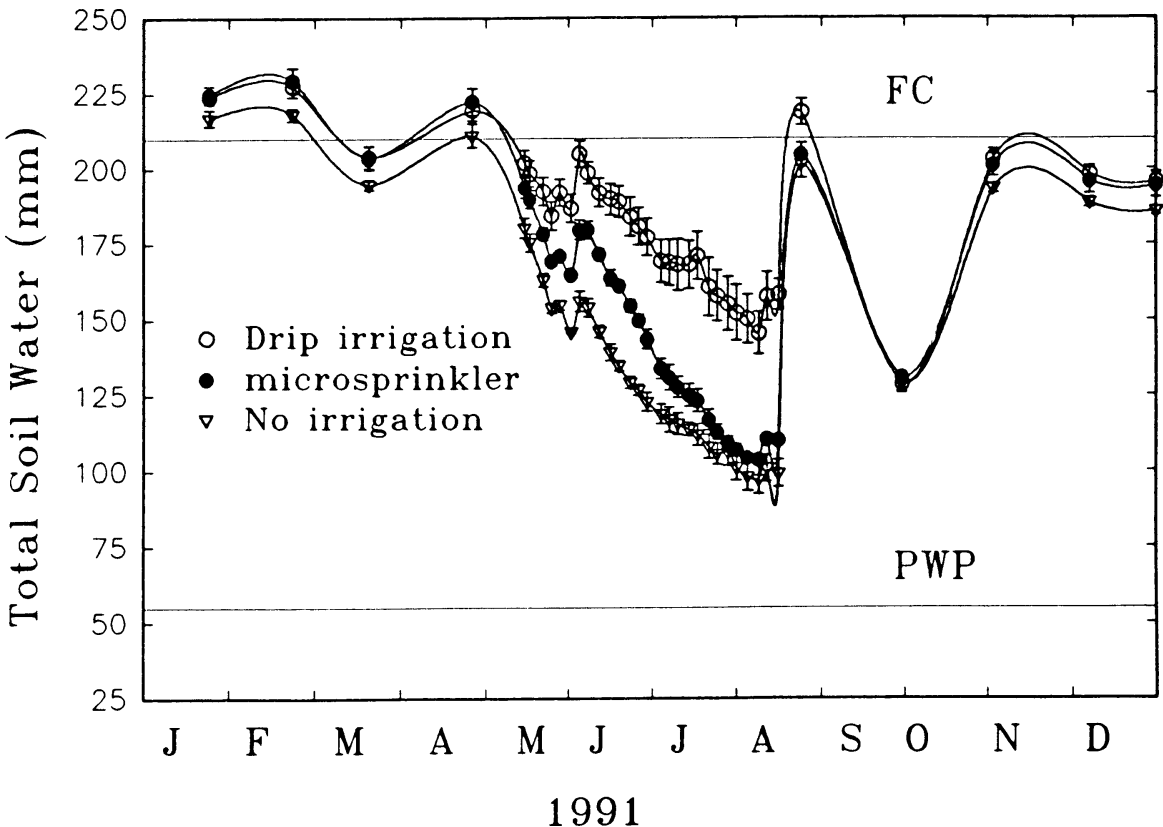

Fig. 1. Total soil water (in millimeters) in soil profile (0- to 110-cm depth) in 1991. Error bars are the SE of the mean for drip, microsprinkler, and nonirrigated treatments.

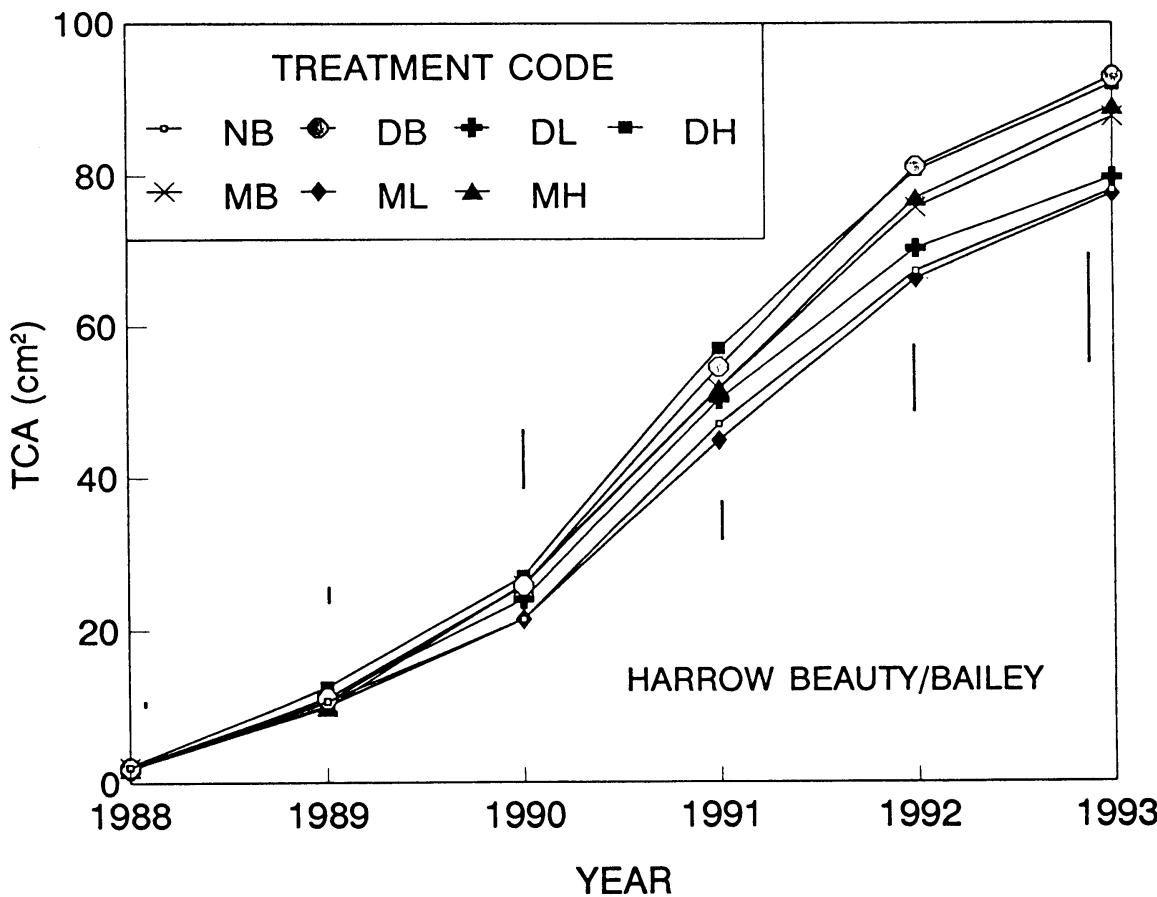

Fig. 2. Cumulative trunk cross-sectional area (in square centimeters) from 1988 to 1993 with least signifificant difference (LSD) at 0.05 bars. Treatment code: $\mathrm{NB}=$ nonirrigated, banded fertilizer; $\mathrm{DB}=$ drip irrigated, banded fertilizer; $\mathrm{DL}=$ drip irrigated, low fertigation; $\mathrm{DH}=$ drip irrigated, high fertigation; $\mathrm{MB}=$ microsprinkler irrigated, banded fertilizer; $\mathrm{ML}=$ microsprinkler irrigated, low fertigation; $\mathrm{MH}=$ microsprinkler irrigated, high fertigation. Vertical bars represent LSD at 0.05 for treatments. 
A significant effect was noted for $\mathrm{Mg}$ concentrations in July samples. DL resulted in significantly higher $\mathrm{Mg}$ concentrations than the other treatments, except NB. However, there were no significantly different treatment effects for September samples.

Miscellaneous micronutrients. Nutrient analyses for $\mathrm{Mn}, \mathrm{Fe}$, and $\mathrm{Zn}$ were within the normal recommended ranges for Ontario (in $\mathrm{mg} \cdot \mathrm{kg}^{-1}$ ): $\mathrm{Mn}=20$ to $200, \mathrm{Fe}=25$ to 200 , and $\mathrm{Zn}=15$ to 100 . There were no significant treatment effects on these nutrient concentrations (data not shown).

$T C A$. There was a general sigmoidal pattern of tree growth with a distinct lag phase from the first (1988) to the third year (1990), a more rapid increase in growth from the third (1990) to the fifth (1992) year, and reduced growth from the fifth to the sixth year (1993) (Fig. 2). Differences among treatments were statistically significant only in the fourth (1991) and fifth (1992) years. The largest trees in 1991 were under $\mathrm{DH}, \mathrm{DB}, \mathrm{MB}$, and $\mathrm{MH}$, and the smallest trees were under MB and ML. In 1992 and 1993, the largest trees were under $\mathrm{DH}, \mathrm{DB}, \mathrm{MH}$, and $\mathrm{MB}$, and the smallest were under DL, NB, and ML.

Total yield. There was a generally linear increase in total yield from the first (1990) to the fourth cropping year for each of the seven treatments (Fig. 3). However, only in 1992 were treatment effects significantly different in the $\mathrm{F}$ test, with $\mathrm{DH}$ and $\mathrm{MB}$ having the highest yields. The pooled data for total yield over the four years indicated that, while there was a large and significant year effect, there was no significant treatment effect or treatment $\times$ year interaction (Table 3 ).
Marketable yield. In the first three cropping years (1990-92) (Fig. 4), yields under each of the seven treatments increased almost linearly. In the fourth cropping year (1993), they leveled off for six of the seven treatments. The decline in yield of DH was most likely due to chance. Only in 1991 and 1992 were marketable yields significantly affected by treatments in the $\mathrm{F}$ test. The highest yielding treatments in both years were $\mathrm{DH}, \mathrm{MB}$, and $\mathrm{DB}$. However, the pooled data over the first 4 years of marketable yields again showed a large and significant year effect, but no significant treatment effect or treatment $\times$ year interaction (Table 4). Regardless of treatment, marketable yields were high in the third and fourth cropping years and exceeded $15 \mathrm{t} \cdot \mathrm{ha}^{-1}$ each year.

Yield efficiency. The seven treatments were equally yield efficient in the first three cropping years (1990-92) (Table 4), but by the fourth cropping year (1993), NB was the most yield efficient; $\mathrm{DB}, \mathrm{DH}$, and $\mathrm{MH}$ were the least yield efficient; and the remaining three (DL, MB, and ML) were intermediate. The seven treatments pooled over the first 4 years of cropping had similar and statistically nonsignificant cumulative yield efficiencies.

\section{Discussion}

As expected, total soil water was lowest in nonirrigated (NB) plots. Although $\approx 50 \%$ less irrigation water was applied to $\mathrm{D}(\mathrm{DB}, \mathrm{DH}$, and $\mathrm{DL}$ ) plots than to $\mathrm{M}$ (MB, MH, ML) plots, total soil water $>110 \mathrm{~cm}$ was higher in D than in M plots. Presumably, more evaporation of water was associated with $M$ than with D plots

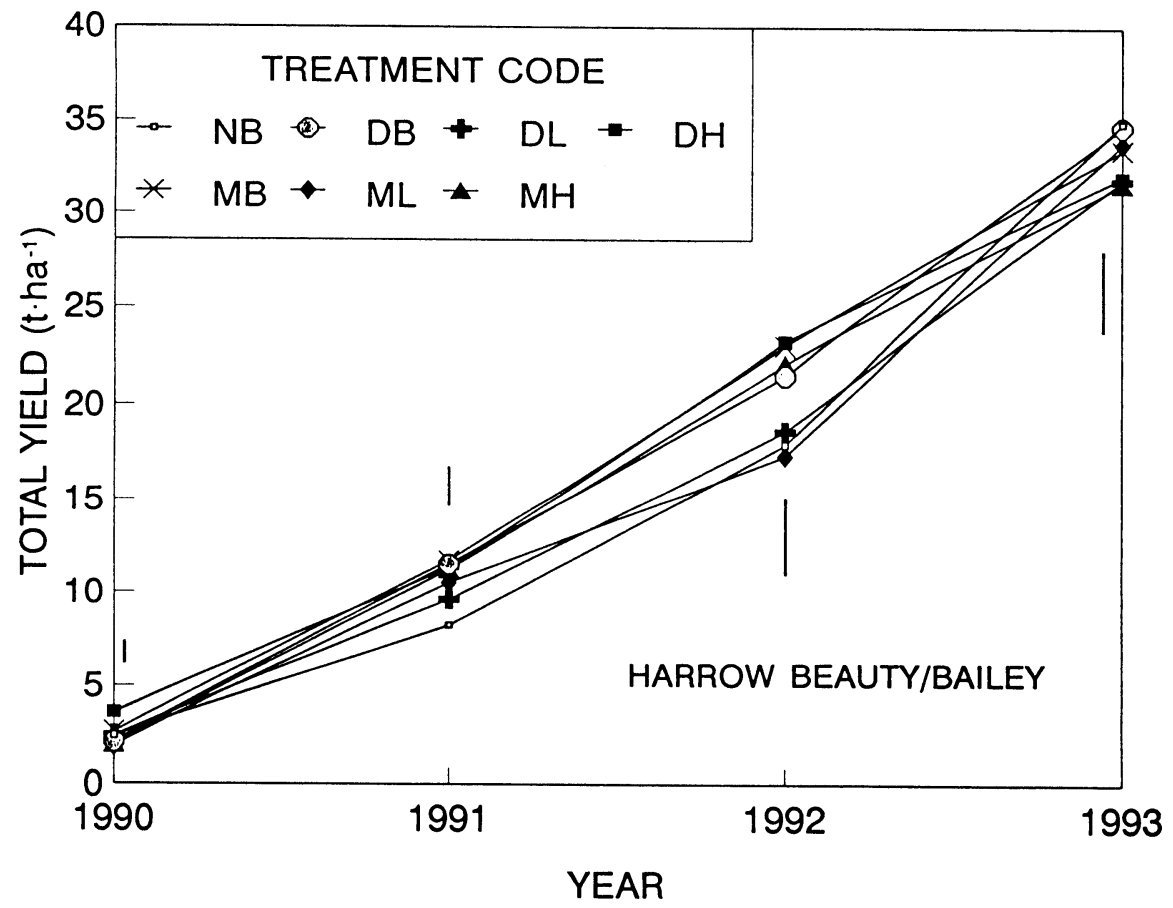

Fig. 3. Total yield (in tons per hectare) in first four cropping years (1990-93). Treatment code: NB = nonirrigated, banded fertilizer; $\mathrm{DB}=$ drip irrigated, banded fertilizer; $\mathrm{DL}=$ drip irrigated, low fertigation; $\mathrm{DH}=$ drip irrigated, high fertigation; $\mathrm{MB}=$ microsprinkler irrigated, banded fertilizer; $\mathrm{ML}=$ microsprinkler irrigated, low fertigation; $\mathrm{MH}=$ microsprinkler irrigated, high fertigation. Vertical bars represent least significant difference at 0.05 for treatments.
Table 3. Average total and marketable yields of 'Harrow Beauty'/Bailey peach in the first 4 years of cropping (1990-93) in response to seven intensive management systems.

\begin{tabular}{|c|c|c|c|}
\hline \multirow[b]{2}{*}{ Treatment $^{\mathrm{y}}$} & & \multicolumn{2}{|c|}{ Mean yield $\left(\mathrm{t} \cdot \mathrm{ha}^{-1}\right)^{\mathrm{z}}$} \\
\hline & & Total & Marketable \\
\hline NB & & 15.8 & 11.9 \\
\hline DB & & 17.5 & 14.2 \\
\hline $\mathrm{DL}$ & & 15.6 & 12.6 \\
\hline $\mathrm{DH}$ & & 17.5 & 14.2 \\
\hline MB & & 17.7 & 14.7 \\
\hline ML & & 15.9 & 12.5 \\
\hline \multirow[t]{2}{*}{$\mathrm{MH}$} & & 16.7 & 13.5 \\
\hline & df & \multicolumn{2}{|c|}{ F test } \\
\hline Treatment & 6 & $0.75^{\mathrm{Ns}}$ & $1.71^{\mathrm{NS}}$ \\
\hline Year & 3 & $549.28^{* * * *}$ & $444.86^{* * *}$ \\
\hline Treatment $\times$ year & 18 & $1.02^{\mathrm{Ns}}$ & $1.06^{\mathrm{NS}}$ \\
\hline
\end{tabular}

${ }^{2}$ Obtained from plot yields.

yTreatment code: $\mathrm{NB}=$ nonirrigated, banded fertilizer; $\mathrm{DB}=$ drip irrigated, banded fertilizer; $\mathrm{DL}=$ drip irrigated, low fertigation; $\mathrm{DH}=$ drip irrigated, high fertigation; $\mathrm{MB}=$ microsprinkler irrigated, banded fertilizer; $\mathrm{ML}=$ microsprinkler irrigated, low fertigation; $\mathrm{MH}=$ microsprinkler irrigated, high fertigation.

NS, ${ }^{* * *}$ Nonsignificant or significant at $P \leq 0.001$, respectively.

because microsprinklers covered a larger surface area at shallower depths, while drip emitters provided a larger volume of water at greater depths (Pelletier and Tan, 1993). In each of the 5 years (1989-93) where irrigation treatments were applied, none of the treatments, including the nonirrigated control(NB), approached the PWP. These results are in contrast with those of Layne et al. (1994a), where total soil water in nonirrigated plots fell below the PWP several times during part of the growing season in some years. The water table in our experiment was usually between 1.0 and $2.0 \mathrm{~m}$ below the soil surface while that of Layne et al. (1994a) at a different site on the same farm was between 2.5 and 3.5 m below the soil surface. Thus, even for the nonirrigated control (NB), a portion of the root system may have been able to access water below the 110$\mathrm{cm}$ depth to avoid measurable drought stress (Layne et al., 1986). Limited measurements of stomatal conductance during the experiment showed no difference among treatments (data not shown).

Leaf $\mathrm{N}$ concentrations in July were usually near the normal recommended range (3.4\% to $4.1 \%$ dry weight) for leaves on bearing peach trees in Ontario, whether $\mathrm{N}$ fertilizer was banded or fertigated. Strabbioli and Colorio (1988) reported similar results for peaches in Italy. No deficiency or toxicity symptoms of $\mathrm{N}$ were noted in the first 5 years that $\mathrm{N}$ was applied. Nitrogen concentrations in July were greater than in September (Table 3), a likely reflection of 1) termination of $\mathrm{N}$ fertigation at the end of June, 2) mobilization of $\mathrm{N}$ from leaves in response to additional demands by the ripening fruit, and 3) mobilization of $\mathrm{N}$ from the leaves before the onset of leaf senescence (Batjer and Westwood, 1958).

Leaf $\mathrm{K}$ concentrations for July were near the normal range recommended for bearing peach orchards in Ontario. None of the treatments resulted in symptoms of $\mathrm{K}$ deficiency or 


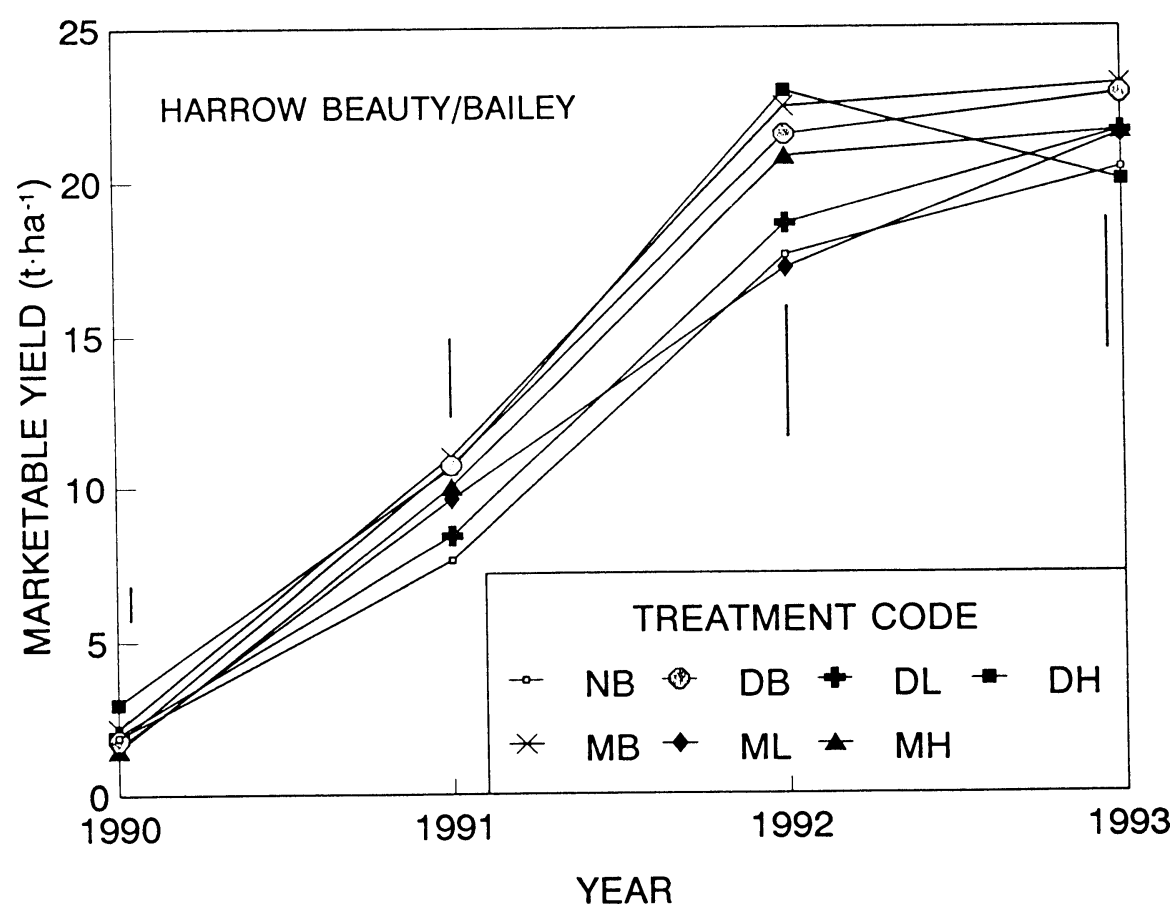

Fig. 4. Marketable yield (in tons per hectare) in the first four cropping years (1990-93). Treatment code: NB $=$ nonirrigated, banded fertilizer; $\mathrm{DB}=$ drip irrigated, banded fertilizer; $\mathrm{DL}=$ drip irrigated, low fertigation; $\mathrm{DH}=$ drip irrigated, high fertigation; $\mathrm{MB}=$ microsprinkler irrigated, banded fertilizer; $\mathrm{ML}$ $=$ microsprinkler irrigated, low fertigation; $\mathrm{MH}=$ microsprinkler irrigated, high fertigation. Vertical bars represent least significant difference at 0.05 for treatments.

Table 4. Yield efficiency of 'Harrow Beauty'/Bailey as affected by seven intensive management systems from the first (1990) to the fourth (1993) year of cropping.

\begin{tabular}{|c|c|c|c|c|c|}
\hline \multirow[b]{2}{*}{ Treatment $^{\mathrm{x}}$} & \multicolumn{4}{|c|}{$\begin{array}{l}\text { Yield efficiency } \\
\left(\mathrm{kg} \cdot \mathrm{cm}^{-2}\right)\end{array}$} & \multirow{2}{*}{$\begin{array}{c}\begin{array}{c}\text { Cumulative yield efficiency } \\
\left(\mathrm{kg} \cdot \mathrm{cm}^{-2}\right)\end{array} \\
1990-93\end{array}$} \\
\hline & 1990 & 1991 & 1992 & 1993 & \\
\hline NB & 0.17 & 0.29 & 0.44 & $0.73 \mathrm{a}^{\mathrm{w}}$ & 1.33 \\
\hline $\mathrm{DB}$ & 0.13 & 0.35 & 0.43 & $0.62 \mathrm{c}$ & 1.24 \\
\hline $\mathrm{DL}$ & 0.16 & 0.32 & 0.44 & $0.66 \mathrm{a}-\mathrm{c}$ & 1.30 \\
\hline DH & 0.21 & 0.32 & 0.47 & $0.57 \mathrm{c}$ & 1.26 \\
\hline MB & 0.16 & 0.37 & 0.50 & $0.63 \mathrm{ab}$ & 1.33 \\
\hline ML & 0.14 & 0.39 & 0.43 & $0.72 \mathrm{ab}$ & 1.35 \\
\hline MH & 0.12 & 0.37 & 0.48 & $0.59 \mathrm{c}$ & 1.33 \\
\hline F test & NS & NS & NS & $* *$ & NS \\
\hline
\end{tabular}

${ }^{2}$ Yield efficiency $=$ kilogram plot per trunk cross-sectional area (TCA).

${ }^{y}$ Cumulative yield efficiency $=\Sigma[($ kilogram/plot $)(1990-1993)] \div$ TCA per plot $(1993)$.

${ }^{x}$ Treatment code: $\mathrm{NB}=$ nonirrigated, banded fertilizer; $\mathrm{DB}=$ drip irrigated, banded fertilizer; $\mathrm{DL}=$ drip irrigated, low fertigation; $\mathrm{DH}=$ drip irrigated, high fertigation; $\mathrm{MB}=$ microsprinkler irrigated, banded fertilizer; $\mathrm{ML}=$ microsprinkler irrigated, low fertigation; $\mathrm{MH}=$ microsprinkler irrigated, high fertigation . "Mean separation of treatments in columns by Duncan's multiple range test at $P \leq 0.05$.

${ }^{\mathrm{Ns},}{ }^{* *}$ Nonsignificant or significant at $P \leq 0.01$, respectively.

toxicity. Leaf K concentrations in September usually were lower than in July, although K fertigation only began at the beginning of July. Presumably, because $\mathrm{K}$ is normally mobile in sandy soils and within the tree, it likely was rapidly taken up by the tree and incorporated into the leaves, contributing to the high $\mathrm{K}$ concentrations in July. Lower concentrations of $\mathrm{K}$ in leaves in September were likely the result of $\mathrm{K}$ movement from the leaves to the developing fruit during size increase and ripening (Batjer and Westwood, 1958), which would have occurred primarily in August, and also movement of $\mathrm{K}$ from leaves to stems and roots.

Cumulative yield efficiency for the first 4 years of cropping was not significantly different among the seven treatments, but for 1993,
Layne et al., 1994a). It is too early, therefore, to draw final conclusions from this experiment, which is at its midpoint. Unlike the earlier experiments on this soil type, where irrigation was advantageous (Layne and Tan, 1984; Layne et al., 1994a), this experiment has not yet demonstrated a significant advantage for irrigation. The combinations of a higher water table in this site compared to the other two sites as well as wetter growing seasons during this experiment reduced the response to irrigation compared with that obtained in the other two long-term experiments. Fertigation of $\mathrm{N}$ and $\mathrm{K}$ did not appear to be any better than the conventional practice, where $\mathrm{N}$ and $\mathrm{K}$ are applied separately in single doses in a band around the drip line of the tree. Similar results also have been reported by Strabbioli and Colorio (1988). Presumably, spring and summer rains were sufficient to move $\mathrm{N}$ and $\mathrm{K}$ from the soil surface to the rooting zone in B treatments to permit adequate nutrient uptake. In Bussi et al.'s (1991) study, the responses to fertigation were greater than those for B treatments, but that study was conducted in a less humid environment.

It is noteworthy that for the first 6 years of this experiment, none of the seven treatments was clearly unsatisfactory in terms of total soil water, tree growth, nutritional status, fruit production, and yield efficiency, including the nonirrigated control (NB). For each year that irrigation was applied (1989-93), seasonal precipitation was higher than the long-term mean (Table 2), and total soil water was never at or below the PWP. Thus, drought stress was never an important factor affecting growth and yield, even for NB. Presumably, the lack of significant drought stress, together with the high water table, were the main reasons that average total and marketable yields for the first 4 years of cropping were similar (Table 3 ). Fruit bearing surface (TCA) increased significantly each year (Fig. 2), as did total and marketable yields (Figs. 3 and 4), but these changes were more attributable to differences in tree age and climatic variables than to treatment effects because the year effect on yields was large and highly significant (Table 3), while the treatment effect was small and nonsignificant. There were no significant treatment $\times$ year interactions; thus, each treatment produced a similar tree response over the first 6 years of growth and the first 4 years of fruit production and, thereby, yield efficiency (Fig. 2, Tables 3 and 4). Each of the seven treatments led to high yields and resulted in a high proportion of marketable fruit in the first 4 years of cropping (Table 3).

In the first 5 years of our experiment, fertigation did not provide a significant enough yield advantage over banded application to warrant the added cost of the fertigation equipment and higher labor requirement associated with this treatment.

\section{Literature Cited}

Batjer, L.P. and M.N. Westwood. 1958. Seasonal trend of several nutrient elements in leaves and fruits of Elberta peach. Proc. Amer. Soc. Hort. Sci. 71:116-126.

HortScience, Vol. 31(3), June 1996 ker infection for this experiment. Such effects are usually more apparent in the declining years of an orchard (Layne and Tan, 1984; the smaller trees associated with NB were more yield efficient than the larger ones assotrees are often more yield efficient than larger ones because there is more dry-matter partigetative growth (Layne and Jui, 1994)

It has been our experience with peach of experimentation usually are required to growth, fruit production, and tree (Layne and Tan, 1984; Layne et al., 1994a). To date, there have been no significant treatment effects on tree survival, winter injury, or can- 
Biggs, A.R. 1989. Integrated approach to controlling Leucostoma canker of peach in Ontario. Plant Dis. 73:771-773.

Bussi, C., J.-G. Huguet, and H. Defrance. 1991. Fertilization scheduling in peach orchards under trickle irrigation. J. Hort. Sci. 66:487-493.

Edwards, H.H., R.R. Bruce, B.D. Horton, J.L. Chesness, and E.J. Wehunt. 1982. Soil cation and water distribution as affected by $\mathrm{NH}_{4} \mathrm{NO}_{3}$ applied through a drip irrigation system. J. Amer. Soc. Hort. Sci. 197:1142-1148.

Haynes, R.J. 1985. Principles of fertilizer use for trickle irrigated crops. Fert. Res. 6:235-255.

Haynes, R.J. and R.S. Swift. 1987. Effect of trickle fertigation with three forms of nitrogen on soil $\mathrm{pH}$, levels of extractable nutrients below the emitter and plant growth. Plant \& Soil 102:211221.

Jones, J.B. 1984. Plants, p. 38-64. In: S. Williams (ed.). Official methods of analysis of the Association of Official Analytical Chemists. 16th ed. Assn. Offic. Anal. Chemists, Arlington, Va.

Layne, R.E.C. and P.Y. Jui. 1994. Genetically diverse peach seedling rootstocks affect longterm performance of 'Redhaven' peach on Fox sand. J. Amer. Soc. Hort. Sci. 119:1303-1311.
Layne, R.E.C., and C.S. Tan. 1984. Long-term influence of irrigation and tree density on growth, survival, and production of peach. J. Amer. Soc. Hort. Sci. 109:795-799.

Layne, R.E.C. and C.S. Tan. 1988. Influence of cultivars, ground covers, and trickle irrigation on early growth, yield, and cold hardiness of peaches on Fox sand. J. Amer. Soc. Hort. Sci. 113:518-525.

Layne, R.E.C., C.S. Tan, and D.M. Hunter. 1994a. Cultivar, ground cover, and irrigation treatments and their interactions affect long-term performance of peach trees. J. Amer. Soc. Hort. Sci. 119:12-19.

Layne, R.E.C., C.S. Tan, and L. Huffman. 1994b. Regional demonstration peach orchards: A success story for southwestern Ontario. Can. Fruitgrower May:2-3.

Layne, R.E.C., C.S. Tan, and R.L. Perry. 1986. Characterization of peach roots in Fox sand as influenced by sprinkler irrigation and tree density. J. Amer. Soc. Hort. Sci. 111:670-677.

Neilsen, G.H., P. Parchomchuck, E.J. Hogue, W.D. Wolk, and O.L. Lau. 1994. Response of apple trees to fertigation-induced soil acidification. Can. J. Plant Sci. 74:347-351.
Neilsen, G.H., P. Parchomchuck, W.D. Wolk, and O.L. Lau. 1993. Growth and mineral composition of newly planted apple trees following fertigation with N and P. J. Amer. Soc. Hort. Sci. 118:50-53.

Ontario Ministry of Agriculture and Food. 1994 1995. Fruit production recommendations. Ontario Ministry of Agriculture and Food Publ. 360.

Pelletier, J. and C.S. Tan. 1993. Determining irrigation wetting patterns using time domain reflectometry. HortScience 28:338-339.

Strabbioli, G. and G. Colorio. 1988. Le pêcher en Italie. Arboriculture Fruitière 406 Mai:60-63.

Tan, C.S. and R.E.C. Layne. 1990. Irrigation scheduling for fruit crops. Ont. Ministry Agr. and Food Agdex 210/560.

Tan, C.S. and R.E.C. Layne. 1991. Soil water content and stomatal conductance in a mature peach orchard as influenced by various irrigation regimes. Can. Soil Sci. 71:253-258.

Townshend, J.L., R.A. Cline, V.A. Dirks, and C.F Marks. 1984. Assessment of turf grasses for the management of Pratylenchus penetrans and Pratylenchus projectus in orchards. Can. J.Plant Sci. 64:355-360. 